\title{
A Role for Mucolytics and Expectorants in Aiding Inhaled Therapies in Asthma? [Response To Letter]
}

\author{
Ramesh J Kurukulaaratchy $\mathbb{D}^{1-4}$ \\ Hitasha Rupani' \\ Wei Chern Gavin Fong ${ }^{2,3}$ \\ Aref Kyyaly (iD) 2,3 \\ 'Department of Respiratory Medicine, \\ University Hospitals Southampton NHS \\ Foundation Trust, Southampton, UK; \\ ${ }^{2}$ Clinical and Experimental Sciences, \\ University of Southampton, \\ Southampton, UK; ${ }^{3}$ David Hide Asthma \\ and Allergy Research Centre, Isle of \\ Wight NHS Trust, Isle of Wight, UK; \\ ${ }^{4} \mathrm{NIHR}$ Biomedical Research Centre, \\ University Hospitals Southampton NHS \\ Foundation Trust, Southampton, UK
}

Correspondence: Ramesh J

Kurukulaaratchy

Wei Chern Gavin Fong Clinical and

Experimental Sciences, University of

Southampton, Southampton, UK

Tel +44 238I20 5232

Email R.J.Kurukulaaratchy@soton.ac.uk;

W.C.Fong@soton.ac.uk

\section{Dear editor}

We are grateful to Urakov and Urakova for their interest in our review article "Recent Insights into the Management of Inflammation in Asthma". ${ }^{1} \mathrm{We}$, in turn, read with interest their associated recent correspondence suggesting a potential role for aerosolized expectorants and mucolytics in augmenting asthma therapies such as inhaled corticosteroids (ICS). ${ }^{2}$ We thank them for highlighting the relevance of mucus hypersecretion in the context of asthma. We agree that mucus hypersecretion is a potentially associated feature of numerous often problematic asthma phenotypes, including allergic fungal airways disease, ${ }^{3}$ overlap bronchiectasis, ${ }^{4}$ dual Chronic Obstructive Pulmonary Disease (COPD) ${ }^{5}$ asthmatic granulomatosis ${ }^{6}$ and asthma with chronic rhinosinusitis and nasal polyps. ${ }^{7}$ It may therefore have particular prominence in the context of more difficult-to-treat asthma and facilitate poorer asthma outcomes. Aberrant expression of gel-forming mucins such as MUC5AC and MUC5B have been identified as pivotal to the generation of abnormal mucus in asthma. ${ }^{8}$ Recognised guideline-advocated asthma treatments, such as the long-acting antimuscarinic agent tiotropium, are known to have potential mucus attenuating actions inhibiting mucus gland hypertrophy and decreasing the number of MUC5AC-positive goblet cells. ${ }^{9}$ Macrolide antibiotics have also shown efficacy in chronic asthma management through immunomodulatory actions that may encompass mucus-modifying effects..$^{10,11}$

The role of mucolytic agents in chronic airways diseases has long been recognised. The evidence base for the efficacy and safety of using mucolytics in conditions like COPD has been more rigorously assessed than in asthma. For example, a recent Cochrane review of mucolytics in COPD showed reductions in exacerbations, hospitalizations and disability days alongside few significant side-effects. However, improvements in quality of life or mortality were not observed. ${ }^{12}$

The role of mucolytic or expectorant agents in asthma therefore has potential plausibility, as does the concept raised by Urakov that such agents might confer better access for ICS and other inhaled therapies to reach the asthmatic airway epithelium by virtue of facilitating airway clearance. ${ }^{2}$ At present, any supporting evidence base for such a recommendation for use in patients with asthma is limited and therefore not contained within mainstream asthma management guidelines. Small studies have previously reported the potential utility of such approaches in asthmatic patients without significant risk with regard to inhaled N-acetylcysteine in asthma. ${ }^{13}$ However, there was also at least one report of fatal anaphylaxis to 
intravenous $\mathrm{N}$-acetylcysteine in an asthmatic patient recorded in the literature. ${ }^{14}$ More recent experimental mouse models of novel mucolytic agents demonstrated improved mucus ultrastructure, transport and protection from airflow obstruction, highlighting the possibility that these may have the potential to be developed into patientfacing therapies in the future. ${ }^{15}$ In addition, benefits of another novel mucolytic, monoterpene 1,8-cineole (eucalyptol), have been shown with regard to improvements in lung function, quality of life and nocturnal symptoms in patients with poorly controlled asthma. ${ }^{16}$ Mucus hypersecretion should be considered as part of the growing list of acknowledged treatable traits in airways diseases, but for the moment evidence-based treatment recommendations to address that trait in asthma are yet to be clearly defined. ${ }^{17}$ We would therefore suggest that the therapeutic role of mucolytics and expectorants in promoting airway clearance and improving airway deposition of inhaled treatments in specific asthma phenotypes is certainly worthy of further rigorous research. We look forward to seeing the findings of such work in the future.

\section{Disclosure}

HR reports speaker and consultancy fees from AstraZeneca, GlaxoSmithKline, Teva, and Novartis and research grant funding from GlaxoSmithKline. WCGF reports ownership of AstraZeneca, GlaxoSmithKline And BioNTech shares. The aforementioned authors report no other potential conflicts of interest for this communication. $\mathrm{AK}$ and RJK have no relevant conflicts of interest for this communication to declare.

\section{References}

1. Rupani H, Fong WCG, Kyyaly A, Kurukulaaratchy RJ. Recent insights into the management of inflammation in asthma. $J$ Inflamm Res. 2021;14:4371-4397. doi:10.2147/JIR.S295038

2. Urakov A, Urakova N. Recent insights into the management of inflammation in asthma [Letter]. $J$ Inflamm Res. 2021;14:4603-4604. PMID: 34548806; PMCID: PMC8449642. doi:10.2147/JIR.S337690

3. Mistry H, Ajsivinac Soberanis HM, Kyyaly MA, et al. The clinical implications of Aspergillus fumigatus sensitization in difficult-to-treat asthma patients. J Allergy Clin Immunol Pract. 2021:S2213-2198(21) 00996-X. doi:10.1016/j.jaip.2021.08.038
4. García-Clemente M, Enríquez-Rodríguez AI, Iscar-Urrutia M, et al. Severe asthma and bronchiectasis. J Asthma. 2020;57(5):505-509. PMID: 30784336. doi:10.1080/02770903.2019.1579832

5. Kostikas K, Clemens A, Patalano F. The asthma-COPD overlap syndrome: do we really need another syndrome in the already complex matrix of airway disease? Int J Chron Obstruct Pulmon Dis. 2016;11:1297-1306. doi:10.2147/COPD.S107307

6. Wenzel SE, Vitari CA, Shende M, Strollo DC, Larkin A, Yousem SA. Asthmatic granulomatosis: a novel disease with asthmatic and granulomatous features. Am J Respir Crit Care Med. 2012;186 (6):501-507. PMID: 22773731. doi:10.1164/rccm.201203-0476OC

7. Martínez-Rivera C, Crespo A, Pinedo-Sierra C, et al. Mucus hypersecretion in asthma is associated with rhinosinusitis, polyps and exacerbations. Respir Med. 2018;135:22-28. PMID: 29414449. doi:10.1016/j.rmed.2017.12.013

8. Bonser LR, Erle DJ. Airway mucus and asthma: the role of MUC5AC and MUC5B. J Clin Med. 2017;6(12):112. PMID: 29186064; PMCID: PMC5742801. doi:10.3390/jcm6120112

9. Bos IS, Gosens R, Zuidhof AB, et al. Inhibition of allergen-induced airway remodelling by tiotropium and budesonide: a comparison. Eur Respir J. 2007;30(4):653-661. PMID: 17537779. doi:10.1183/ 09031936.00004907

10. Gibson PG, Yang IA, Upham JW, et al. Effect of azithromycin on asthma exacerbations and quality of life in adults with persistent uncontrolled asthma (AMAZES): a randomised, double-blind, placebo-controlled trial. Lancet. 2017;390(10095):659-668. doi:10.1016/S0140-6736(17)31281-3

11. Morinaga Y, Yanagihara K, Miyashita N, et al. Azithromycin, clarithromycin and telithromycin inhibit MUC5AC induction by Chlamydophila pneumoniae in airway epithelial cells. Pulm Pharmacol Ther. 2009;22(6):580-586. PMID: 19716898. doi:10.1016/j.pupt.2009.08.004

12. Poole P, Sathananthan K, Fortescue R. Mucolytic agents versus placebo for chronic bronchitis or chronic obstructive pulmonary disease. Cochrane Database Syst Rev. 2019;2019(5):CD001287.

13. Millman M, Millman FM, Goldstein IM, Mercandetti AJ. Use of acetylcysteine in bronchial asthma-another look. Ann Allergy. 1985;54(4):294-296. PMID: 3985424.

14. Appelboam AV, Dargan PI, Knighton J. Fatal anaphylactoid reaction to N-acetylcysteine: caution in patients with asthma. Emerg Med J. 2002;19(6):594-595. PMID: 12421803; PMCID: PMC1756296. doi:10.1136/emj.19.6.594

15. Morgan LE, Jaramillo AM, Shenoy SK, et al. Disulfide disruption reverses mucus dysfunction in allergic airway disease. Nat Commun. 2021;12(1):249. PMID: 33431872; PMCID: PMC7801631. doi:10.1038/s41467-020-20499-0

16. Juergens LJ, Worth $\mathrm{H}$, Juergens UR. New perspectives for mucolytic, anti-inflammatory and adjunctive therapy with 1,8-cineole in COPD and asthma: review on the new therapeutic approach. Adv Ther. 2020;37(5):1737-1753. PMID: 32200535; PMCID: PMC7467491. doi:10.1007/s12325-020-01279-0

17. Agusti A, Bel E, Thomas M, et al. Treatable traits: toward precision medicine of chronic airway diseases. Eur Respir J. 2016;47 (2):410-419. doi:10.1183/13993003.01359-2015 
Dove Medical Press encourages responsible, free and frank academic debate. The content of the Journal of Inflammation Research 'letters to the editor' section does not necessarily represent the views of Dove Medical Press, its officers, agents, employees, related entities or the Journal of Inflammation Research editors. While all reasonable steps have been taken to confirm the content of each letter, Dove Medical Press accepts no liability in respect of the content of any letter, nor is it responsible for the content and accuracy of any letter to the editor.

Journal of Inflammation Research

Dovepress

\section{Publish your work in this journal}

The Journal of Inflammation Research is an international, peerreviewed open-access journal that welcomes laboratory and clinical findings on the molecular basis, cell biology and pharmacology of inflammation including original research, reviews, symposium reports, hypothesis formation and commentaries on: acute/chronic inflammation; mediators of inflammation; cellular processes; molecular

mechanisms; pharmacology and novel anti-inflammatory drugs; clinical conditions involving inflammation. The manuscript management system is completely online and includes a very quick and fair peerreview system. Visit http://www.dovepress.com/testimonials.php to read real quotes from published authors.

Submit your manuscript here: https://www.dovepress.com/journal-of-inflammation-research-journal 